\title{
EDUKASI KESIAPSIAGAAN BANJIR DI KELURAHAN SILABERANTI LORONG DAHLIA PALEMBANG
}

\author{
Miskiyah Tamar $^{1}$, Siti Romadoni ${ }^{2}$, Puji Setya Rini ${ }^{3}$ \\ ${ }^{1,2,3}$ Program Studi Ilmu Keperawatan, IKesT Muhammadiyah Palembang, Jln A Yani 13 Ulu, \\ Palembang \\ Email: miskiyahtamar1986@gmail.com
}

\begin{abstract}
ABSTRAK
Bencana banjir merupakan peristiwa yang mengancam dan mengganggu kehidupan dan penghidupan masyarakat yang disebabkan oleh aliran air yang tingginya melebihi muka air normal sehingga melimpah dan menyebabkan adanya genangan pada lahan rendah. Limpahan yang terus meluap akan menimbulkan genangan-genangan yang semakin tinggi pada lahan yang lebih rendah sehingga mengakibatkan timbulnya korban jiwa manusia, kerusakan lingkungan, kerugian harta benda, dan dampak psikologis. Tujuan dalam kegiatan pengabdian masyarakat ini yaitu untuk membantu peningkatan pengetahuan tentang kesiapsiagaan banjir bagi warga. Pelaksanaan kegiatan ini berupa pendidikan kesehatan dengan menggunakan metode ceramah, diskusi dan tanya jawab menggunakan tayangan video animasi terkait edukasi kesiapsiagaan banjir bagi warga. Sasaran dalam kegiatan ini yaitu warga Kelurahan Silaberanti Lorong Palembang Dahlia yang kooperatif. Kegiatan pengabdian ini dilaksanakan dalam tiga tahapan kegiatan yaitu persiapan, pelaksanaan dan evaluasi. Hasil yang didapatkan yaitu adanya peningkatan pengetahuan tentang kesiapsiagaan banjir sebelum dan sesudah dilaksanakan kegiatan pengabdian masyarakat berupa tayangan video animasi.
\end{abstract}

Kata kunci: Edukasi, Kesiapsiagaan, Banjir

\section{EDUCATION FOR FLOOD PREPAREDNESS IN LORONG DAHLIA SILABERANTI PALEMBANG}

\begin{abstract}
Catastrophic flooding is a threatening event that disrupts people's lives and livelihoods caused by the flow of water that exceeds normal water levels so abundant and causes inundation on low land. The continued overflow will cause higher inundation on lower land resulting in human fatalities, environmental damage, property losses, and psychological impacts.The purpose of this community service activity is to help increase knowledge about flood preparedness for residents. The implementation of this activity in the form of health education using lecture methods, discussions and using animated video views related to flood preparedness education for residents. The target in this activity is the residents of Silaberanti Lorong Palembang Dahlia Village who are cooperative. This devotional activity is carried out in three stages of activities, namely preparation, implementation and evaluation. The result is an increase in knowledge about flood preparedness before and after community service activities in the form of animated video views.
\end{abstract}

Keywords: Education, Preparedness, Flooding

\section{PENDAHULUAN}

Negara Indonesia merupakan negara maritim dimana sebagian besar wilayahnya terdiri dari wilayah perairan kurang lebih 70,8 \% dari luas permukaan bumi yang luasnya 510 juta $\mathrm{km}^{2}$, oleh karena itu persediaan air di wilayah Indonesia relatif melimpah terlebih saat musim penghujan, (Wahyuningsih, 2014). Intensitas curah hujan yang cukup tinggi tersebut menjadikan Indonesia sebagai kawasan rawan bencana banjir (BNPB, 2016). Kejadian dan korban bencana banjir 
menempati urutan pertama di dunia yaitu mencapai 55\%. Presentase kejadian banjir di Indonesia mencapai 38\% (Bakornas, 2015).

Banjir merupakan suatu keadaan yang terjadi pada saat aliran air melebihi volume air (Direktorat Sungai, 2014). Banjir membawa dampak bagi masyarakat antara lain korban jiwa, hilangnya mata pencaharian, hilangnya harta benda, kerusakan rumah, dan kerusakan fasilitas umum (Mistra, 2015). Data BMKG Kenten, Palembang termasuk kawasan rawan banjir. Kota Palembang dihuni 1.753 .532 jiwa (11, januari 2019). Dengan kepadatan penduduk 4.800 per $\mathrm{km}^{2}$. Seiring dengan bertambahnya kepadatan penduduk, lahan hijau sudah berubah menjadi pemukiman.

Berdasarkan observasi lapangan yang dilakukan di kelurahan Silaberanti lorong Dahlia merupakan pemukiman yang padat penduduk, dengan jumlah KK 32 atau 128 jiwa, dan intensitas curah hujan yang tinggi, membuat kawasan ini sering terjadi banjir jika hujan deras selama \pm 4-5 jam dan akan tergenang setinggi $\pm 40 \mathrm{~cm}$ dan selama \pm 3 jam jika hujan berhenti, hal ini akan terjaadi selama musim hujan.

Berdasarkan wawancara yang dilakukan peneliti kepada ketua RT Lorong Dahlia dampak banjir bagi masyarakat berupa terganggunya aktifitas masyarakat, dampak kesehatan yaitu diare dan DBD . Dataran lorong Dahlia yang sebagian merupakan dataran keras sehingga untuk penyerapan air kurang maksimal. Dari hasil observasi peneliti saluran pembuangan air penuh dengan sampah dan tanah. Sebelumnya belum ada kesadaran dari masyarakat untuk melakukan pencegahan banjir. Oleh karena itu masyarakat perlu melakukan suatu usaha penanggulangan bencana banjir guna memperkecil dampak bencana banjir. Terlebih dahulu, masyarakat harus memiliki pengetahuan kesiapsiagaan banjir setelah itu masyarakat baru bisa mengambil sikap (Purwoko, 2015).

Pengetahuan merupakan upaya untuk mengurangi resiko dan dampak kerugian dari bencana (Pribadi,2014). Pengetahuan merupakan faktor utama dan menjadi kunci untuk kesiapsiagaan. Pengetahuan yang dimiliki biasanya dapat memengaruhi sikap dan kepedulian untuk siap siaga dalam mengantisipasi bencana (UU No. 24, 2007). Kesiapsiagaan merupakan salah satu bagian dari proses manajemen bencana, (LIPI-UNESCO, 2006 dalam purwoko, 2015).

Salah satu media yang cukup relevan dalam menumbuhkan pengetahuan kesiapsiagaan adalah dengan video animasi (Zamriz, 2015). Video animasi termasuk jenis media audio visual, karena terdapat gerakan gambar dan suara. Animasi dapat memberikan pengalaman belajar yang lebih bermakna dan memberikan stimulus yang lebih besar dibandingkan membaca buku teks karena pesan berbentuk audio visual dan gerakan pada video animasi ini memberikan kesan impresif bagi penontonnya. Hasil penelitian uji t diperoleh nilai p 0,00 lebih kecil dari 0,05. (Wahyu, 2015). Salah satu cara yang dapat digunakan untuk menumbuhkan tindakan kesiapsiagaan masyarakat adalah dengan penyajian video animasi kesiapsiagaan (Ferawaty, 2017). 
Bencana banjir merupakan peristiwa yang mengancam dan mengganggu kehidupan dan penghidupan masyarakat yang disebabkan oleh aliran air yang tingginya melebihi muka air normal sehingga melimpah dan menyebabkan adanya genangan pada lahan rendah. Limpahan yang terus meluap akan menimbulkan genangan-genangan yang semakin tinggi pada lahan yang lebih rendah sehingga mengakibatkan timbulnya korban jiwa manusia, kerusakan lingkungan, kerugian harta benda, dan dampak psikologis (Mistra, 2015).

Dari beberapa teori penelitian terkait dan juga studi pendahuluan yang dilakukan maka kami tertarik untuk melakukan kegiatan pengabdian masyarakat berupa edukasi kesiapsiagaan banjir dengan video animasi bagi warga Kelurahan Silaberanti Lorong Dahlia Palembang.

\section{MASALAH}

Berdasarkan observasi lapangan yang telah dilakukan di kelurahan Silaberanti lorong Dahlia merupakan pemukiman yang padat penduduk, dengan jumlah KK 32 atau 128 jiwa, dan intensitas curah hujan yang tinggi, membuat kawasan ini sering terjadi banjir jika hujan deras selama \pm 4-5 jam dan akan tergenang setinggi $\pm 40 \mathrm{~cm}$ dan selama \pm 3 jam jika hujan berhenti, hal ini akan terjaadi selama musim hujan. Berdasarkan wawancara yang dilakukan kepada ketua RT Lorong Dahlia dampak banjir bagi masyarakat berupa terganggunya aktifitas masyarakat, dampak kesehatan yaitu diare dan DBD . Dataran lorong Dahlia yang sebagian merupakan dataran keras sehingga untuk penyerapan air kurang maksimal. Dari hasil observasi diketahui saluran pembuangan air penuh dengan sampah dan tanah. Sebelumnya belum ada kesadaran dari masyarakat untuk melakukan pencegahan banjir. Oleh karena itu masyarakat perlu melakukan suatu usaha penanggulangan bencana banjir guna memperkecil dampak bencana banjir. Terlebih dahulu, masyarakat harus memiliki pengetahuan kesiapsiagaan banjir setelah itu masyarakat baru bisa mengambil sikap (Purwoko, 2015).

Salah satu media yang cukup relevan dalam menumbuhkan pengetahuan kesiapsiagaan adalah dengan video animasi (Zamriz, 2015). Video animasi termasuk jenis media audio visual, karena terdapat gerakan gambar dan suara. Animasi dapat memberikan pengalaman belajar yang lebih bermakna dan memberikan stimulus yang lebih besar dibandingkan membaca buku teks karena pesan berbentuk audio visual dan gerakan pada video animasi ini memberikan kesan impresif bagi penontonnya. Hasil penelitian uji t diperoleh nilai p 0,00 lebih kecil dari 0,05. (Wahyu, 2015). Salah satu cara yang dapat digunakan untuk menumbuhkan tindakan kesiapsiagaan masyarakat adalah dengan penyajian video animasi kesiapsiagaan (Ferawaty, 2017).

Dari beberapa teori penelitian terkait dan juga studi pendahuluan yang dilakukan maka kami tertarik untuk melakukan kegiatan pengabdian masyarakat berupa edukasi kesiapsiagaan banjir dengan video animasi bagi warga Kelurahan Silaberanti Lorong Dahlia Palembang.

\section{METODE PELAKSANAAN}


Sasaran dalam kegiatan pengabdian masyarakat ini yaitu semua warga Kelurahan Silaberanti Lorong Dahlia Palembang menggunakan tayangan video animasi berupa peningkatan edukasi tentang kesiapsiagaan banjir. Kegiatan pengabdian ini dilaksanakan dalam tiga tahapan kegiatan yaitu persiapan, pelaksanaan dan evaluasi.

1. Persiapan dimulai dari penyusunan proposal kegiatan, pembuatan Standar Operasional kegiatan, perincian kegiatan yang dilakukan, pembagian tugas pada saat pelaksanaan kegiatan (tugas ketua, anggota dan tim pelaksana yang dibantu oleh mahasiswa). Setelah semua persiapan selesai ketua pelaksana juga menyiapkan surat perijinan tempat pelaksanaan kegiatan.

Studi pendahuluan dilaksanakan dengan menggunakan data primer yang diperoleh dari hasil wawancara langsung dengan beberapa warga Kelurahan Silaberanti Lorong Dahlia dan data sekunder diperoleh dari data Kelurahan Silaberanti.

Persiapan instrumen untuk pengambilan data kegiatan berupa video animasi dan kuesioner.

2. Tahap kedua yaitu pelaksanaan berupa home visit dengan menemui keluarga sebagai subjek dalam kegiatan pengabmas untuk diberi penjelasan tentang cara proses pengambilan data dan etika pengabmas.

Diberikan kuesioner sebelum dilaksanakan kegiatan, kemudian melakukan intervensi pendidikan kesehatan melalui edukasi menggunakan video animasi selama 4 menit dan membagikan kembali kuesioner untuk mengambil nilai kembali pengetahuan kesiapsiagaan banjir setelah di lakukan intervensi dengan jeda 5 menit.

3. Tahap ketiga yaitu dilakukan evalusi kegiatan berupa dilaksanakannya analisa data sebelum dan setelah dilaksanakan kegiatan pendidikan kesehatan. Analisa data yang diguanakan yaitu analisa univariat untuk melihat distribusi frekuensi pengetahuan sebelum dan sesudah diberikan pendidikan kesehatan.

\section{HASIL DAN PEMBAHASAN}

Hasil yang didapatkan dalam kegiatan pengabdian masyarakat berupa pendidikan kesehatan menggunakan tayangan video animasi untuk peningkatan pengetahuan tentang kesiapsiagaan banjir Kelurahan Silaberanti Lorong Dahlia berupa data univariat untuk melihat distribusi frekuesi pengetahuan sebelum dan sesudah dilaksanakan kegiatan. Pengumpulan data menggunakan kuesioner yang dibagikan pada masing-masing responden penelitian.

\section{Tabel 1}

Hasil Tes Normalitas Sebelum dan Sesudah Dilakukan Edukasi Kesiagsiagaan Banjir Kelurahan Silaberanti Lorong Dahlia Palembang

Tests of Normality

\begin{tabular}{llllll}
\multicolumn{2}{c}{ Kolmogorov-Smirnov ${ }^{\text {a }}$} & \multicolumn{3}{c}{ Shapiro-Wilk } \\
\hline Statistic & df & Sig. & Statistic & df & Sig. \\
\hline
\end{tabular}




(5)) Khidmah.ikestmp.ac.id
P-ISSN : 2654-864X

\section{Tabel 2}

Rerata Sebelum dan Sesudah Dilakukan Edukasi Kesiagsiagaan Banjir Kelurahan Silaberanti Lorong Dahlia Palembang

\begin{tabular}{cccccc}
\hline & Mean & Median & Std Deviasi & Min - Max & P Value \\
\hline Pre Test & 36.27 & 40.00 & 13.243 & $8-56$ & 0.00 \\
\hline Post Test & 83.20 & 88.00 & 12.535 & $56-96$ & \\
\hline
\end{tabular}

Analisa univariat dari total 30 responden diatas menunjukkan bahwa sebelum dilakukan kegiatan pengabdian masyarakat menggunakan video animasi berupa edukasi kesiapsiagaan banjir secara statistik didapatkan nilai mean 36.27, nilai median 40.00 dan standar deviasi 13.243.

Analisa univariat dari total 30 responden diatas menunjukkan bahwa sesudah dilakukan kegiatan pengabdian masyarakat menggunakan video animasi berupa edukasi kesiapsiagaan banjir secara statistik didapatkan nilai mean 83.20, nilai median 88.00 dan standar deviasi 12.535. Analisa bivariat dari total 30 responden diatas menunjukkan nilai $\mathrm{p}$ value $0,000(\mathrm{p}<0,05)$ berarti secara statistik ada pengaruh edukasi kesiapsiagaan banjir dengan menggunakan video animasi.

Hasil dari analisa univariat dan analisa bivariat yaitu didapatakan Analisa univariat dari total 30 responden diatas menunjukkan bahwa sebelum dilakukan kegiatan pengabdian masyarakat menggunakan video animasi berupa edukasi kesiapsiagaan banjir secara statistik didapatkan nilai mean 36.27, nilai median 40.00 dan standar deviasi 13.243. Analisa univariat dari total 30 responden diatas menunjukkan bahwa sesudah dilakukan kegiatan pengabdian masyarakat menggunakan video animasi berupa edukasi kesiapsiagaan banjir secara statistik didapatkan nilai mean 83.20, nilai median 88.00 dan standar deviasi 12.535. Analisa bivariat dari total 30 responden diatas menunjukkan nilai $p$ value $0,000(\mathrm{p}<0,05)$ berarti secara statistik ada pengaruh edukasi kesiapsiagaan banjir dengan menggunakan video animasi.

Dari hasil penelitian yang dilakukan di Kelurahan Silaberanti Lorong Dahlia Palembang faktor yang mempengaruhi pengetahuan masyarakat adalah Pendidikan karena Pendidikan mempengaruhi proses belajar, makin tinggi pendidikan seseorang semakin mudah orang tersebut menerima informasi. Dengan pendidikan tinggi, maka seseorang akan semakin cenderung untuk mendapatkan informasi, baik dari orang lain maupun dari media massa. Semakin banyak informasi yang masuk semakin banyak pula pengetahuan yang didapat. 
Faktor lain yang memepengaruhi pengetahuan adalah usia karena usia mempengaruhi daya tangkap dan pola pikir seseorang. Semakin bertambah usia akan semakin berkembang pula daya tangkap dan pola pikirnya sehingga pengetahuan yang diperolehnya semakin membaik. Tetapi hal ini tidak berlaku pada usia lansia karena telah mengalami kemunduran baik fisik maupun mental. Dapat diperkirakan IQ akan menurun sejalan dengan bertambahnya usia, khususnya pada beberapa kemampuan yang lain, seperti kosa kata dan pengetahuan umum. Beberapa teori berpendapat ternyata IQ seseorang akan menurun cukup cepat sejalan dengan bertambahnya usia.

Serta faktor lingkungan karena lingkungan adalah segala sesuatu yang ada di sekitar individu, baik lingkungan fisik, biologis, maupun sosial. Lingkungan berpengaruh terhadap proses masuknya pengetahuan kedalam individu yang berada dalam lingkungan tersebut. Hal ini terjadi karena adanya interaksi timbal balik ataupun tidak, yang akan direspon sebagai pengetahuan oleh setiap individu (Notoatmodjo, 2012).

Pengetahuan merupakan upaya untuk mengurangi resiko dan dampak kerugian dari bencana (Pribadi,2014). Pengetahuan merupakan faktor utama dan menjadi kunci untuk kesiapsiagaan. Pengetahuan yang dimiliki biasanya dapat memengaruhi sikap dan kepedulian untuk siap siaga dalam mengantisipasi bencana (UU No. 24, 2007). Kesiapsiagaan merupakan salah satu bagian dari proses manajemen bencana, (LIPI-UNESCO, 2006 dalam purwoko, 2015).

Sesuai dengan teori yang dikemukakan Notoatmodjo (2014), yang menyatakan bahwa upayaupaya yang dapat dilakukan untuk meningkatkan pengetahuan seseorang adalah pendidikan. Pendidikan dapat berupa penyuluhan, karena penyuluhan merupakan salah satu jenis layanan yang merupakan bagian terpadu dari bimbingan. Penyuluhan adalah hubungan timbal balik antara individu dengan orang lain yang berusaha membantu untuk mencapai pengertian tentang dirinya sendiri dalam hubungan dengan masalah yang dihadapi pada waktu yang akan datang.

Salah satu media yang cukup relevan dalam memberikan pendidikan kesehatan atau penyuluhan tentang pengetahuan kesiapsiagaan adalah dengan video animasi (Zamriz, 2015). Video animasi termasuk jenis media audio visual, karena terdapat gerakan gambar dan suara. Animasi dapat memberikan pengalaman belajar yang lebih bermakna dan memberikan stimulus yang lebih besar dibandingkan membaca buku teks karena pesan berbentuk audio visual dan gerakan pada video animasi ini memberikan kesan impresif bagi penontonnya. Hasil penelitian uji t diperoleh nilai p 0,00 lebih kecil dari 0,05. (Wahyu, 2015). Salah satu cara yang dapat digunakan untuk menumbuhkan tindakan kesiapsiagaan masyarakat adalah dengan penyajian video animasi kesiapsiagaan (Ferawaty, 2017).

Hasil penelitian ini sejalan dengan penelitian yang dilakukan oleh Wahyu (2015), tentang Pengaruh Penggunaan Media Video Animasi "Siaga Bencana Gunung Berapi" Terhadap Kesiapsiagaan Siswa Kelas V Di Sd Negeri Kepuharjo, didapatkan hasil uji dari 33 responden 
diperoleh hasil $\mathrm{p}$ value $0.000<0,05$. Dengan demikian H1 diterima yang berarti ada Pengaruh Penggunaan Media Video Animasi "Siaga Bencana Gunung Berapi” Terhadap Kesiapsiagaan Siswa Kelas V Di Sd Negeri Kepuharjo,.

Berdasarkan hasil penelitian serta teori yang ada maka peneliti berpendapat bahwa ada pengaruh sebelum dan setelah dilakukan pendidikan kesehatan terhadap terhadap pengetahuan masyarakat tentang kesiapsiagaan banjir. Dalam penelitian ini pemberian pendidikan kesehatan ini menggunakan media video animasi. Metode media animasi dalam penelitian ini membantu masyarakat untuk lebih memahami dan dapat menerapkan isi atau informasi yang diberikan saat dilakukan pendidikan kesehatan. Hal tersebut dapat membantu dalam penelitian, masyarakat akan lebih mengingat dalam menerima informasi. Hal ini dapat terlihat terdapat perubahan signifikan pengetahuan responden tentang kesiapsiagaan banjir sebelum dan setelah diberikan pendidikan kesehatan. Perhatian yang responden berikan menunjukkan adanya minat dalam pemberian pendidikan kesehatan menggunakan metode pendidikan kesehatan melalui video animasi, dengan hal tersebut juga akan mempengaruhi pengetahuan responden.

\section{KESIMPULAN}

Kesimpulan yang didapat yaitu hasil analisa bivariat dari total 30 responden diatas menunjukkan nilai $\mathrm{p}$ value $0,000(\mathrm{p}<0,05)$ berarti secara statistik ada pengaruh edukasi kesiapsiagaan banjir dengan menggunakan video animasi.Dari hasil tersebut tampak bahwa adanya peningkatan pengetahuan setelah dilakukan kegiatan pengabdian masyarakat berupa pendidikan kesehatan.

\section{UCAPAN TERIMA KASIH}

1. Ucapan terima kasih terutama ditujukan kepada pihak IKesT Muhammadiyah Palembang dalam memfasilitasi kegiatan ini dan memberi bantuan dana kegiatan

2. Ucapan terima kasih terutama ditujukan kepada pihak Kelurahan Silaberanti dalam memfasilitasi kegiatan ini berupa mengeluarkan ijin kegiatan, mempersiapkan lahan dan mendukung dengan penuh kegiatan ini

3. Ucapan terima kasih terutama ditujukan kepada warga Lorong Dahlia yang bersedia sebagai peserta kegiatan

\section{DAFTAR PUSTAKA}

Bakornas Pb. (2015). Pengenalan Karakteristik Bencana Dan UpayaMitigasinya Di Indonesia. Jakarta: Badan Nasional Penanggulangan Bencana. 
BNPB (2010). Panduan Pengenalan Karakteristik Bencana Dan Upaya Mitigasinya diIndonesia, Jakarta, BNPB.

Chandra, (2015). Ilmu Kedokteran Pencegahan dan Komunitas. Jakarta. EGC

Ciptaning, Maria. (2014). Keperawatan Gawatdarurat dan Manajemen Bencana, Jakarta. Pusdik SDM Kesehatan.

Dina Utami. (2013). Animasi Dalam Pembelajaran. Online. http://journal.uny.ac.id/index.php/mip/article/view/3212/2692. Diakses pada 11 Januari 2019 pukul 11.00 WIB.

Firmansyah, I. (2014) Hubungan pengetahuan dengan perilaku kesiapsiagaan dalam menghadapi bencana banjir dan longsor pada remaha usia 15-18 tahun di SMA Al-Hasan Kemiri Kecamatan Panti Kabupaten Jember. Program Studi Ilmu Keperawatan Universtias Jember; 2014.

Gultom, Agustina Boru. (2014). Pengaruh Pengetahuan Dan Sikap Terhadap Kesiapsiagaan Tenaga Kesehatan Puskesmas Kampung Baru Menghadapi Bencana Banjir Di Kecamatan Medan Maimun. Tesis.Medan: Fakultas Kesehatan Masyarakat Universitas SumateraUtara.

Hammond, Zimmermann. (2013). Keperawatan Gawatdarurat dan Manajemen Bencana Sheeh (Yanny Trisyani \& Ikaristi Maria, Penerjemah). Jakarta: Pusdik SDM Kesehatan Indiantoro. Pengetahuan Masyarakat terhadap Mitigasi Bencana Kekeringan di Kecamatan Tawangsari Kabupaten Sukoharjo. Universita Gadjah Mada Yogyakarta; 2014.

LIPI - UNESCO/ISDR, (2014). Kajian Kesiapsiagaan Masyarakat DalamMengantisipasi Bencana Gempa Bumi \& Tsunami, Jakarta. Deputi Ilmu Pengetahuan Kebumian Lembaga Ilmu Pengetahuan Indonesia.

Munir. (2013). Multimedia Konsep Dan Aplikasi Dalam Pendidikan. Bandung : Cv Alfabeta

Pangesti, A. (2013). Gambaran tingkat pengetahuan dan aplikasi kesiapsiagaan bencana pada mahasiswa Fakultas Ilmu Keperawatan Universitas Indonesia tahun 2012. Universitas Indonesia

Pusponegoro, AD. (2016). Kegawatdaruratan Bencana. Jakarta: PT. Rayyana Komunikasindo.

Sopaheluwakan. Jan, Deni Hidayati, Haryadi Permana dkk. Lipi - Unesco/Isdr. (2006). Kajian Kesiapsiagaan Masyarakat Dalam Mengantisipasi Bencana Gempa Bumi \& Tsunami. Deputi Ilmu Pengetahuan Kebumian Lembaga Ilmu Pengetahuan Indonesia, Jakarta.

Sulistiyaningrum, Ferawaty. (2017). Pengaruh Penggunaan Media Video Animasi "Siaga Bencana Gunung Berapi” Terhadap Kesiapsiagaan Siswa Kelas V Di Sd Negeri Kepuharjo.

Wahyu, Ika. (2015). Pengaruh Film Animasi Terhadap Motivasi Belajar Pada Anak TK.

Wahyuningsih, Tri. (2014).Pengaruh Pengetahuan Dan Sikap Masyarakat Terhadap Kesiapsiagaan Menghadapi Bencana Banjir Di Kelurahan Joyotakan Kecamatan Serengan Kota Surakarta. 
Widiastuty, (2018). Pengembangan Video Pembelajaran Erupsi Gunung Api Untuk Meningkatkan Pengetahuan Pada Subtema Kondisi Alam Indonesia di Kelas VII Smp Negeri 1 Selo Boyolali.

Wulandari, (2018). Pengaruh Media Video Terhadap Kesiapsiagaan Siswa dalam Menghadapi Bencana Gempa bumi Di Sma Negeri 1 Gantiwarno, Klaten. 